\title{
MENGURANGI DEGRADASI MORAL DAN PENGUATAN KARAKTER ANAK MELALUI PERAN CATUR GURU DI TENGAH PANDEMI COVID-19
}

\author{
Oleh: \\ Putu Febri Sri Suandari ${ }^{1}$, Ni Nengah Selasih ${ }^{2}$ \\ ${ }^{1,2}$ Universitas Hindu Negeri I Gusti Bagus Sugriwa Denpasar \\ e-mail: febrisrisuandari@gmail.com
}

Diterima: 31 Mei 2021, Direvisi: 09 September 2021, Diterbitkan: 18 Oktober 2021

\begin{abstract}
Abstrak
Pendidikan merupakah salah satu hal sangat penting yang mampu menjadi pegerak perubah dunia serta dalam mengubah generasi muda menjadi lebih baik dan berkarakter. Dengan adanya sebuah pendidikan yang dilengkapai oleh ajaran agama itu sendiri akan membuat penguatan karakter serta mengurangi degradasi atau kemerosotan moral serta etika yang terjadi pada setiap anak penerus bangsa. Penanam nilai-nilai budi pekerti luhur, etika serta ajaran-ajaran agama haruslah ditanam sejak dini sehingga anak menjadi terbiasa akan hal tesebut serta mampu memahami prilakuprilaku yang patut dijauhi dan dilarang. Oleh karena itu peran orang tua sangatlah berpengaruh terhadap karakter anak kerena keluarga merupakan pendidikan dasar atau yang utama yang didapatkan oleh anak. Selain itu untuk mengurangi degradasi atau kemerosotan moral saat ini yang marak terjadi di dalam kehidupan, maka perlunya ada kerjasama antar orang tua,tenaga pendidik serta pemerintah untuk dapat menciptakan generasi muda yang baik. Oleh karena itu Catur Guru memiliki peranan yang sangat penting dalam mengurangi degradasi moral serta penguatan karakter anak. Guru Rupaka dan Guru Pengajian sebagai pendidikan formal dan non formal yang didapatkan oleh anak, haruslah saling bersinergi dalam mendidik,membentuk karakter anak serta menanamkan ajaran-ajaran etika,moral, budi pekerti dan pendidikan agama dalam diri anak sejak dini. Dan didukung oleh Guru Wisesa atau pemerintah dalam pembuatan peraturan di dunia pendidikan.
\end{abstract}

Kata Kunci: Degradasi, Penguatan karakter, Catur guru

\begin{abstract}
Education is one of the most important things that is able to be a change in the world and in changing the younger generation to be better and have character. With the existence of an education that is complemented by religious teachings it self, it will streng then character and reduce the moral and ethical degradation or decline that occurs in every nation's future child. Cultivators of noble moral values, ethics and religious teachings must be planted from an early age so that children become accustomed to them and are able to understand behaviors that should be avoided and prohibited. Therefore the role of parents is very influential on the character of the child because the family is the primary or primary education that the child gets. In addition, to reduce the current moral degradation or deterioration that is prevalent in life, there is a need for cooperation between parents, educators and the government to be able to
\end{abstract}


create a good young generation. Therefore, Catur guru has a very important role in reducing moral degradation and strengthening children's character. Guru Rupaka and Guru Pengajian as formal and non-formal education obtained by children, must synergize with each other in educating, shaping children's character and instilling ethical, moral, character and religious teachings in children from an early age. And supported by Guru Wisesa or the government in making regulations in the world of education.

Keywords: Degradation, Character strengthening, Catur guru

\section{PENDAHULUAN}

Melihat fenomena-fenomena yang terjadi saat ini akan degradasi moral suatu bangsa sangatlah menghawatirkan dan tidak asing lagi di dengar. Kasus- kasus tindakan amoral seperti penghaniayaan terhadap guru, orang tua, teman, pemerasan, bullying, pencurian, seks bebas, trek-trekana di jalan sudah biasa terjadi, ini membuktikan berapa hebatnya kemerosatan degradasi moral saat ini (Sudarsana, 2011). Di sinilah seharusnya pendidikan berperan aktif, karena pendidikan yang baik merupakan pendidikan yang mampu dalam membentuk karakter positif dalam diri anak. Selain itu penanaman pendidikan agama adalah salah satu usaha konkret yang harus ditekankan dan diterapkan baik itu secara formal maupun non formal sebagai penanggulangan atau mengatasi degradasi moral dan krisis karakter (Darta, 2020). Proses belajar diperlukan untuk menambah wawasan ataupun pegetahuan sehingga dari pengetahuan tersebut kita dapat membenahi diri menjadi pribadi yang lebih baik lagi. Oleh karena itu pendidikan sangatlah yamg mampu mengubah kehidupan bangsa serta membentuk karakter anak yang berbudi luhur. Selain itu karakter merupakan suatu nilai yang bersifat fundamental yang artinya memiliki karakter yang mendasar serta kuat yang tidak dapat lepas dari pembentukan kepribadian individu. Pembentukan dan penguatan suatu karakter bagi anak haruslah ditanam sejak dini sehingga mereka menjadi terbiasa dan mampu terciptanya generasi muda yang berkarakter dimasa depan. Oleh karena itu pihak orang tua serta tenaga pendidik haruslah saling bekerjasama dan berkontribusi dalam menanam dan menguatkan nilai karakter sehingga tidak terjadinya kemerosotan moral atau degradasi moral pada diri anak. Melihat perkembangan zaman sekarang banyak sekali anak maupun generasi muda yang mengalami degredasi moral,etika dan sopan santun terhadap Catur Guru ini. Catur Guru merupakan empat guru yang yang patut di hormati antara lain seperti; guru rupaka,swadyaya, pengajian dan wisesa. Banyak sekali anak-anak zaman sekarang yang tidak bhakti dan hormat terhadap catur guru ini seperti sering memaki orang tuanya, berantem, melupakan kewajibanya untuk belajar, sembhayang, ugal-ugalan dalam berkendaraan, tercerumus narkoba, seks bebas, melanggar peraturaan lalu lintas bahkan anak-anak sekarang sudah berani melakukan tindakan-tindakan kriminal lainya. Ini menandakan bahwa generasi penerus sekarang mengalami degredasi moral dan pemerosotan karakter yang sangat luar biasa. Selain itu dalam situasi dunia sekarang yang begitu kacau terjadi karena munculnya pandemic covid-19 saat ini, banyak sekali terjadinya permasalahan seperti ekonomi, pekerjaan serta berdampak juga terhadap dunia pendidikan yang harus ditutup sementara,sehingga berdampak pula juga terhadap anak-anak ataupun peserta didik yang diharuskan belajar dari rumah secara mandiri. Akibat pembelajaraan yang dilakukan dirumah saja banyak anak yang menjadi malas belajar,membuat tugas bahkan dalam pembuatan tugasnya 
melibatkan orang tuanyalah yang membuat tugas mereka sedangkan mereka malahan asik dalam bermain games. Dan sikap ini sudah berpantangan dengan ajaran catur guru sendiri. oleh karena itu pentingnya kerjasama orang tua, pendidik dan pemerintah dalam mengembalikan atau menguragi degradasi moral dan menguatkan karakter anak yang berbudi pekerti luhur sehingga mampu menjadi anak ataupun generasi muda bangsa yang baik bagi bangsa dan Negara. Selain itu sepatutnya orang tua harus mampu menanamkan nilai-nilai budi pekerti dan karakter sejak dini yang dimana keluarga merupakan dasar yang pertama dalam menerima pendidikan. Itulah alasanya mengapa penanaman karakter serta pendidikan sangatlah penting didapatkan oleh setiap orang yang dimana pendidikan memiliki tujuan seperti yang tercamtum dalam UUD mengenai sistem pendidikan nasional No.20 tahun 2003 pasal 3 yang dimana menyatakan bahwa tujuan pendidikan ialah mampu dalam mengembangkan potensi peserta didik sehingga dapat menjadi manusia yang beriman dan bertakwa kepada Tuhan Yang Maha Esa,berakhlak mulia,sehat,berilmu,cakap,kreatif mandiri dan menjadi warga Negara yang demokratis serta bertanggung jawab(Ramadhani, 2020). Selain itu pendidikan atau ajaran agama sejak dini juga sangatlah penting bagi anak yang dimana ajaran agama bila anak mengetahui serta memahaminya sejak dini maka anak tidak akan mengalami kemerosotan moral karena telah mampu memiliah prilaku buruk dan benar. Sehingga mampu terwujudnya tujuan hidup yang disebut dengan istilah "Moksatam Jagadita Ya Ca Iti Dharma" yang artinya ialah tujuan hidup manusia yaitu untuk mencapai kesejateraan serta kebahagiaan dalam hidup maupun akhirat (Suardana, n.d.). tidak hanya itu saja dasar gerak dalam suatu pendidikan agama ialah tiada lain terdiri dari satyam,siwam dan sundaram yang artinya kebenaran (kejujuran),kebajikan, serta kedamaian atau keindahan yang mampu membangun keharmonisan antar sesama (Arta Jaya, 2019).

\section{METODE}

Metode yang digunakan dalam tulisan ini ialah menggunakan metode deskriptif kualitatif yang merupakan metode penelitan yang memanfaatkan data kualitatif serta dilanjukatkan dengan menggambarkan atau menjabarkan secara deskriptif mengenai degradasi moral yang terjadi pada diri anak ditengah Covid 19 serta penguatan karakter melalui peran catur guru di tengah situasi saat ini. Metode ini digunakan untuk dapat menganalisi fenomena ataupun kejadian sosial yang terjadi. Teknik pengumpulan data dalam tulisan ini ialah mengunakan studi kepustakaan (library research) yaitu dengan menyimak dan mencatat melalui buku bacaan,jurnal dan melihat fenomena yang terjadi pada saat sekarang dengan teknik mengamati baik secara langsung ataupun melalui sumber-sumber media berita yang telah terekpos.

\section{PEMBAHASAAN}

\subsection{Covid-19 Menjadi Pendukung Degradasi Moral Pada Diri Anak}

Degradasi moral ialah suatu pemerosotan moral ,tingkah laku,cara beretika dan lainya yang akhir-akhir ini menjadi permasalahan. Krisis moral ini terjadi karena ada beberapa faktor yang memperngaruhinya seperti; arus globalisasi, penyalahgunaan teknologi,pola asuh anak yang tidak benar,kurangnya penananama ajaran-ajaran agama dan budi pekerti,factor lingkungan sekitar maupun factor pergaulan bebas (Dwi Lestari, Ida Ayu, Sutriyanti, 2020). Degradasi moral atau pemerosotan moral ini sangatlah 
berbahaya dan bersifat buruk bagi anak dan generasi muda sebagai penerus bangsa dikedepanya. Selain itu degradasi moral ini telah merajalela dan semakin marak ketika didukung oleh situasi pandemic covid -19 saat ini. Yang dimana degradasi moral ini menjadi begitu meningkat seperti contoh lunturnya tata karma,tata kesopanan dan beretika terhadap Catur Guru. Saat adanya peraturan berlangsung mengenai pembelajaran daring oleh pemerintah yang memperlakukan pembelajaraan di rumah malah membuat peserta didik hilangnya rasa tanggung jawab belajar mereka. Seperti yang pernah terjadi pada akhir-akhir ini, yang dimana pendidik atau guru memeberikan tugas kepada siswa namun peserta didik tersebut malahan tidak mau mengerjakanya dan menyuruh orang tuanya ataupun kakaknya untuk mengerjakan tugas sekolah tersebut. Disisi lain juga ada tindakan-tindakan kriminal seperti melakukan pencurian uang, sepeda montor,handphone,leptop dan lain sebagainya yang dilakukan oleh anak karena keterpaksaan serta kondisi ekonomi yang kurang dalam keluarga. Bahkan tragisnya anak-anak mencuri hal tesebut agar bisa mengikuti pembelajaran daring di tengah pandemic. Hal ini seharus tidak terjadi apabila setiap anak memiliki nilai-nilai moral dan penguatan karakter yang baik. Ini menandakan bahwa degradasi moral ini sangatlah miris sekali. Dan sudah bertentangan terhadap ajaran catur guru itu sendiri, degradasi moral anak yang terjadi pada guru swadyaya seperti; tidak melakukan persembhayangan, melakukan pantangan-pantangan yang dilarang agama, melakukan hal-hal yang tercela dan lain sebagainya, degradasi moral anak yang terjadi pada guru rupaka seperti; melawan perintah orang tua,berkelahin terhadap orang tua, tidak hormat dan bhakti terhadap orang tua,berkata kasar dan sering mencaci maki orang tua dan lain sebagainya, selanjutnya degradasi moral anak yang terjadi pada guru pengajian seperti; berani menetang dan berkasar terhadap guru,tidak patuh dan hormat terhadap guru, mencela guru tidak mengerjakan tugas yang telah diberikan oleh guru,dan yang terakhir yaitu degradasi moral anak yang terjadi pada guru wisesa seperti tidak taat akan peraturan yang berlaku,ugal-ugalan,melanggar peraturan lalu lintas,balap liar,memakai narkoba,bahkan ada beberapa anak yang terjerat tindakan kriminal.

Krisis moral atau degradasi moral ini menjadi tamparan keras bagi para orang tua, guru maupun pemerintah untuk lebih memperhatikan dan perduli mengenai permasalahan ini. Sehingga disini keberadaan guru rupaka,guru pengajian serta wisesa haruslah bisa berkontribusi bersama dalam memperbaiki degradasi dan menguatkan karakter anak. Dimana orang tua merupakan guru pertama atau pondasi dasar anak dalam menerima pembelajaraan pertamanya disini peran orang tua sangat penting dalam menanamakan nilai-nilai budi pekerti dan ajaran agama sebagai dasar dari kehidupannya, disisilain guru juga harus bisa membimbing,mendidik dan menuntun anak agar tidak terjerumus kehal-hal yang bersifat negative serta pemerintah mampu dalam membuat peraturan-peraturan dalam kehidupan sehingga mampu terciptanya kehidupan yang sejahtera,tertib dan selain itu pemerintah harus terus membenahi kurikulum yang ada sehingga mampu menciptakan generasi bangsa yang cerdas.

\subsection{Penguatan Karakter dan Mengurangi Degradasi Moral melalui Peran Catur Guru}

Pendidikan karakter merupakan tameng serta hal yang sangat penting yang harus ada dalam diri anak dan ditanam sejak dini. Yang dimana karakter ini akan menentukan kepribadian atau watak seorang anak. Pendidikan karaktek menjadi tombak utama dalam mewujudkan genarasi yang berbudi luhur yang dimana berfungsi sebagai pembangunan kehidupan bangsa yang multikultur, mampu dalam membangun 
peradaban bangsa yang berbudaya luhur,cerdas,cakap serta dapat berkontribusi terhadap pengembangan kehidupan manusia, mengembangkan potensi dasar dalam diri, berprilaku, berfikir yang baik, terladan dan mampu membangun sikap kewarganegaraan yang cinta damai, mandiri, kreatif, saling berdampingan, menghormati antar sesama (Sri Mertasari, 2016). Dalam kamus besar bahasa Indonesia Karakter ialah yang berati tabiat,watak, sifat kejiwaan,aklah atau budi pekerti yang dapat membedakan seseorang satu dengan yang lainya. Kepribadian itu bersifat khas dalam diri setiap individu serta berbeda satu dengan yang lainya. Bahkan anak kembar pun memiliki kepribadian yang berbeda-beda. Hal ini disebabkan karena terdapat nilai (values) yang dihayati dalam diri masing-masing setiap orang juga berbeda pula disamping itu pola asuh dari orang tua yang berbeda,serta pengalaman dan pendidikan yang berbeda. Dalam konteks pendidikan karakter maka peran nilai-nilai ini sangat penting adanya dalam membentuk karakter atau kepribadiannya (Mulyadi, Seto, Basuki, Heru, Rahardjo, 2016). Orang dikatakan berkarakter apabila orang tersebut telah terjadi integrasi nilai tertentu dalam dirinya. Pendidikan karakter merupakan upaya sadar yang disegaja maupun terprogramagar mampu menolong manusia menjadi lebih mengerti,peduli serta bertindak berdasarkan nilai etika dengan tujuan supaya mereka mampu mengetahui hal yang baik,benar serta memiliki rasa peduli terhadap apa yang benar,yakin meskipun dalam keadaan yang tertekan dan dilematis (David Ekind \& Freddy Sweet Ph.D 2004).

Selain itu pendidikan tidak hanya semata-mata bertujuan untuk mengajar mata pembelajaran akan tetapi dapat mendidik, menuntun, membesarkan dan mengembangkan kepribadian dalam diri anak. Pendidikan merupakan suatu perwujudan yang dapat membenahi ataupun menyempurnakan sesuatu yang ada dalam diri manusia. Selain itu pendidikan yang secara implinsit mengandung tiga aspek elemen dasar sebagai bentuk keseimbangan kerohanian serta jiwa antara lain seperti; intelektual, estetika dan etika. Suatu intelektual bukan saja sebagai bentuk kecerdasan akan tetapi juga yang berisakan nilai moral serta karakter. Seperti yang dikatakan oleh Bhagawan Sri Sathya Sai Baba (2000:5) yang menyatakan pembentukan karakter yang baik pada anak didik seperti berikut: tujuan pendidikan adalah kearifan, tujuan peradaban adalah kesempurnaan,tujuan kebijaksanaan adalah kebebasan dan tujuan pendidikan adalah karakter yang baik. Sehingga dapat kita simpulkan bahwa pendidikan merupakan hal yang begitu penting dan memiliki peran utama dalam mengubah segalahnya (Suantara, 2020).

Selain itu ajaran agama dan budi pekerti sejak dini juga memiliki peran yang penting pula dalam pembentukan dan penguatan karakter bagi diri anak, sehingga tidak terjadinya pemerosotan atau degradasi moral. Dalam ajaran-ajaran agama banyak sekali terdapat nilai-nilai moral serta nilai budi pekerti luhur yang dapat kita petik dan dijadikan pedoman hidup. Dalam budaya hindu di Bali banyak sekali ajaran-ajaran yang dapat dijadikan pedoman dalam hidup salah satunya ada yang dikenal dengan konsep Catur Guru yaitu kata catur guru berasal dari bahasa Sanskerta yang dimana dari akar kata catur yang berarti empat dan guru yang berarti orang yang memberikan pengetahuan. Sehingga dapat kita simpulkan bahwa catur guru merupakan empat guru yang memiliki peran penting dalam mengajarkan,menuntun manusia akan kehidupan serta nilai-nilai yang lekat dalam kehidupan itu sendiri. Selain itu dalam pustaka suci Taitiriya Upanisad.VII.4 menyatakan sebagai berikut; seorang guru hendaknya dapat mengajarkan,mendidik ataupun menuntun dengan sepenuh hati dan jiwa. Dalam situasi saat ini mengenai degradasi moral yang banyak terjadi dan untuk menguatakan karakter anak peran catur guru ini sangat berpengaruh serta memiliki peran yang sangat penting 
dan merupakan kunci utama dalam pembentukan dan penguatan karakter pada diri anak. Membentuk karakter anak melalui pembelajaraan pandidikan agama hindu merupakan tugas utama dari guru, orang tua serta pemerintah. Ketiga aspek elemen inilah harus bisa bekerjasama dan bersinergi dalam membentuk dan mewujudkan karakter anak yang baik. Catur guru memiliki fungsi serta peran tersendiri dalam perjalanan pendidikan anak. Keberasilan suatau pendidikan dapat dilihat dari kualitas tenaga pendidik maupun proses pembelajaranya, disamping dari kekuasaan Ida Sang Hyang Widhi Wasa yang disebut sebagai guru Swadiyaya. Kualitas Ketiga guru yang disebut dengan Tri Guru yang bersifat nyata ini sangat besar pemgaruhnya terhadap keberasilan pendidikan serta pembentukan karakter anak yang berbudi luhur (Ari Lastini, Ni Nyoman. Anggreni, 2018). Tri guru antara lain seperti; Guru Rupaka (Orang tua dirumah), Guru Pengajian (Guru yang mengajarkan di sekolah) serta Guru Wisesa (Guru Pemerintah). Inilah tri guru yang menjadi tameng serta berperan besar dalam mengajarkan nilai-nilai kehidupan, pembentukan maupun penguatan karakter dalam diri anak (Suardana, n.d.). Berikut peran catur guru dalam penguatan karakter anak.

\section{a. Peran guru rupaka}

Guru reka atau yang biasa juga disebut sebagai guru rupaka ialah peran orang tua yang dimana ini menjadi dasar dan landasan anak dalam menerima pendidikan pertamanya. Disini tanggung jawaban dan kewajiban orang tua mendidikan dan menanamkan nilai-nilai moral, etika serta ajaran agama dalam diri anak sejak dini sehingga mereka menjadi terbiasa dan memiliki karakter yang baik di kedepanya. Sebagai orang tua sepatutnya dapat menasehati anak bila kerap kali berbuat ataupun bertindak salah dan mampu dalam memberikan contoh-contoh prilaku yang baik seperti memberikan contoh ajaran Tri Kaya Parisudha kepada anak seperti berkata yang baik,berbuat yang baik serta berfikir yang baik, Tat Twam Asi aku adalah kamu dan kamu adalah aku, Tri Parartha,Cara beretika,bertatakrama dan menghormati Catur Guru dan ajaran-ajaran lain. Sehingga dari sini anak dapat berfikir sebelum bertindak dan berkata. Lingkungan keluarga merupakan merupakan pondasi anak-anak dalam menerima ajaran pertamanya atau bisa disebut sebagai sekolah pertama dalam mendapatkan pembelajaran atau didikan dalam pembentukan karakter anak. Seperti kata pepatah yang mengatakan bahwa buah jatuh tidak jauh dari pohonya yang dimana dapat kita artikan bahwa seorang anak juga tidak akan jauh berbeda dari sifat atau watak dari orang tuanya orang tuanya. Inilah pentingnya mengapa kita menanakan nilai-nilai moral dan ajaran agama sejak dini pada diri anak sehingga tidak terjadinya degradasi moral.

\section{b. Peran guru pengajian}

Guru pengajian merupakan guru yang mengajar di sekolah setelah orang tua di rumah. Sekolah menajadi salah satu lembaga dalam membentuk atau menumbuh kembangkan nalar berfikir yang kuat melalui ilmu pengetahuan serta teknologi untuk membentuk karakter anak atau peserta didik yang luhur. Pendidikan yang kita dapat disekolah merupakan lanjutan pembentukan dan penguatan karakter yang telah dibentuk dirumah. Dengan dapat belajar disekolah sehinggat dapat menambah daya intelek atau wawasan pengetahuan pada diri anak serta bertujuan agar karakter peserta didik menjadi lebih kuat atau berkarakter dari yang sebelumnya. Sekolah merupakan tempat kedua setelah keluarga dalam penerimaan pendidikan. Disini perlu adanya kesinabungan dan kerjasama antar pendidik dan pihak orang tua dalam pembentukan dan penguatan 
karakter seorang anak. Selain itu pendidik di sekolah juga diharapkan dapat mendidik,membimbing, menuntun serta mengajarkan ajaran-ajaran agama pada diri anak sehingga menjadi pribadi yang baik. Pendidik mengajarkan bagaimana cara berbhakti,hormat terhadap catur guru sehingga tidak terjadinya penyimpangan atau perbuatan amoral. Dengan menjelaskan bahwa anak yang berbhakti dan patuh terhadapa catur guru merupakan anak yang suputra akan tetapi anak yang tidak patuh dan bhakti terhadap catur guru disebut sebagai anak yang alphaka guru dan akan berdosa serta menjelaskan ajaran-ajaran lainya sehingga dapat terciptanya generasi muda yang cerdas dan memiliki karakter yang baik.

\section{c. Peran guru wisesa}

Selanjutnya guru yang tiga ialah guru wisesa atau yang biasa disebut pemerintah. Guru wisesa inilah yang menjadi panutan dan menjadi pamong atau tameng dalam masyarakat. peran guru wisesa dalam penguatan karakter anak ialah dimana pemerintah harus mampu bersikap tegas, disiplin serta mampu dalam membuat peraturan-peraturan yang mengatur masyarakat dan generasi muda menjadi lebih baik dalam kehidupan sehingga tidak terjadinya pelanggaran-pelanggaran etika,moral dan karakter. Di dalam bidang pendidikan pemerintah berwajib memberikan fasilitas ataupun sarana dan pasarana yang lengkap dan memadai di sekolah, sehingga fungsi sekolah sebagai lembaga pendidikan akan bisa lebih efektif serta mampu melahirkan anak bangsa yang menjadi pionir - pionir pembangunan ke arah yang diharapkan. Pemerintah juga harus mampu dalam membuat krurikulum-Kurikulum yang baik sehingga membantu guru dalam mendidik peserta didik. Selain itu pemerintah adalah guru dalam masyarakat umum yang berkewajiban untuk mencerdaskan kehidupan Bangsa dan memberikan kesejahteraan material dan spiritual. Guru wisesa ini juga harus bersinergi dan bekerjasama dengan guru rupaka dan pengajian sehingga mampu menciptakan generasi muda yang berkarakter. Akhir-akhir ini banyak sekali anak-anak kita terjerumus kedalam hal-hal yang negative seperti tindakan kriminal,pencurian,pelecehan seksual,balapan liar dijalan, terjerumus kedalam narkoba dan lain sebagainya. Disini peran ketiga guru ini sangatlah penting dan berpengaruh mengenai etika dan karakter anak. Disini peran guru wisesa sebagai penguat karakter anak adalah mampu mendidik, menuntun anak agar tidak terjerumus ke hal tersebut dengan cara membuat peraturan atau sangsi bagi orang yang melanggar sehingga mereka menjadi jerah jika kerap kali ingin berbuat yang tidak baik.

\section{d. Peran guru swadyaya}

Dan yang terakhir ialah peran dari guru swadyaya. Guru Swadiyaya merupakan Ida Sang Hyang Widhi Wasa itu sendiri yang dimana beliau sebagai pencipta kita dan alam semesta beserta isinya di alam ini. Kesadaran anak akan keberadaan Tuhan di dunia serta hukum sebab akibat atau yang kita kenal dengan Karmaphala harus ditanam sejak dini oleh orang tua serta guru di sekolah. Seorang anak harus diajarkan bahwa setiap perbuatan atau tindakan pastilah akan mengasilkan sesuatu yang sesuai dengan perbuatan kita(Sudarsana, 2011) (Dwi Lestari, Ida Ayu, Sutriyanti, 2020). Memang kita sadari bahwa keberadaan Tuhan tidak bisa kita lihat dan bersifat maha gaib. Walaupun begitu anak-anak yang memiliki pengetahuan spritualitas serta mumpuni dalam ajaraan agama tidak menentang ajaran agama merupakan salah satu sikap bhakti terhadap Tuhan itu sendiri. Peran guru swadiyaya dalam penguatan moral ini tanpa kita sadari sedikit pun apabila kita berbuat adharma dan amoral maka suatu saat nanti kita pasti akan 
menerima gajaran atau hukum dari prilaku kita tersebut. sehingga dalam hal ini guru swadiyaya ini sudah berperan dalam kehidupan kita semua. Kita telah dibekalkan atau diberikan Tri Pramana agar kita dapat membedakan suatu hal yang tergolong baik ataupun buruk yang kita kenal dengan istilah (wiweka). Secara niskala dan sekala keberadaan Tuhan itu ada dan memiliki peran tersendiri.

\subsection{Ajaran Catur Guru sebagai penguatan Karakter di Tengah Pandemi Covid19}

Ajaran catur guru merupakan ajaran agama yang terdapat dalam agama hindu. Sebagai ajaran yeng mendidik serta mebahas bagaimana cara berbhakti dan menghormati catur guru. Guru berarti pebimbing,pendidik ataupun pengajar. Guru sebagai tenaga pendidik memiliki tugas serta tanggung jawab untuk dapat mendidik,menuntun anak maupun peserta didik dari suatu hal yang belum tahu menjadi tahu. Guru sebagai pengajar yang artinya guru dapat mengajarkan kita,mentranfer ilmu pengetahuan kepada peserta didiknya, guru sebagai pelatih karena guru memiliki tugas untuk melatih sikap,mental,keterampilan,spiritual terhadap anak, sedangkan guru sebagai pembimbing artinya guru harus mampu dalam membimbing anak ataupun peserta didik kejalan yang benar (dharma). Saat situasi pandemic covid -19 telah membuat semua bidang dalam kehidupan menjadi berubah begitu signifikan sekali. Tak terkecuali pada bidang pendidikan pula yang pada awalnya menghambat proses pembelajaraan belangsung secara tatap muka. Kini harus melalui media daring dengan menggunakan media seperti Zoom, Google Class Room, Google Meet maupun media sehingga seorang pendidik tidak dapat memantau peserta didik dengan baik dalam mengikuti pembelajaraan. Dengan munculnya situasi pandemic covid-19 ini mendukung terjadinya kemerosatan moral pada diri anak. Oleh sebab itu ajaran catur guru serta peran ke empat guru harus saling bersinergi dalam mengatasi degradasi moral dan karakter anak (Nurhayati, 2020). Sehingga dapat meningkatkan rasa bhakti,anak yang suputra dan suputri dan hormat terhadap catur guru sebagaimana mestinya. Keempat guru ini antara lain sebagai berikut:

a. Guru Swadiyaya ialah bhakti dan hormat terhadap Ida Sang Hyang Widhi Wasa yang dimana beliau sebagai pencipta alam semesta. Beliau disebut sebagai guru karena beliau merupakan pembimbing utama bagi umat manusia yang tidak ada bandinganya. Beliau maha sakti,maha tuhu,maha karya serta maha kuasa. Oleh karena itu kita harus bhakti dan patuh terhadap ajarannya seperti misalnya;

1. Selalu ingat dan selalu bersembhayang terhadap beliau sebgai rasa syukur dan bhakti kita.

2. Menjaga kesucian pura

3. Meyakini kebesaran tuhan

4. Dana punia dan saling monolong

5. Memplajarai ajaran agama dan lain sebagainyai. Sehingga kita dapat meningkatkan pritualitas kita terhadap tuhan.

b. Guru Rupaka ialah bhakti dan hormat kepada orang tua karena beliulah yang telah melahirkan dan membesarkan kita. Tidak hanya itu secara umum orang tua juga memiliki lima jasa terhadap anaknya yang disebut dengan Panca Widha ialah lima jasa orang tua yaitu Ametwaken (telah melahirkan kita), metulung urip(selalu menjaga dan menolong kita), maweh bhinojana (yang telah membesarkan, memberi makan serta minum), anyangaskara (selalu mengupacarai kita dengan upacara manusa yadnya agar selalu selamat dan dilindungi), serta mangupadhyaya (telah 
mendidik dan mengajarkan kita dalam kehidupan ini) (Hindu, 2016). Rasa bhakti dan hormat kepada guru rupaka dapat kita wujudkan seperti;

1. Menjungjung tinggi kehormatan keluarga

2. Selalu mendengarkan nasehat dan didikan orang tua

3. Mematuhi perintah orang tua

4. Melaksankan upacara pitra yajna sebagaimana mestinya

5. Membantu orang tua dalam melakukan tugas serta lain sebagainya

c. Guru Pengajian ialah bhakti dan hormat terhadap guru disekolah yang telah mendidik dan mengajari kita disekolah sehingga kita menjadi tahu dan terhindar dari kebodohan (Yaniasti, 2019). Oleh karena itu kita patut bhakti dan hormat kepada guru disekolah rasa bhakti dan hormat dapat kita wujudkan sebagai berikut;

1. Selalu mengerjakan tugas yang telah diberikan

2. Menaati dan patuh terhadap tata tertib disekolah 3. Tidak mencaci maki guru atau berbuat yang asusila.

4. Tidak menentang guru

5. Menjaga nama baik guru dan sekolah serta lain sebagainya.

d. Guru Wisesa ialah bhakti dan hormat terhadap pemerintah. Yang dimana pemerintah memiliki peran penting dalam pendidikan dan Negara.

Mensejahteraankan rakyat dan sebagai pelindung oleh karena itu kita harus selalu bhakti dan hormat terhadap guru wisesa ini dengan cara seperti berikut;

1. Mematuhi peraturan yang telah dibuat atau ditetapkan

2. Menghargai dan menghormati para pahlawan bangsa

3. Menjungjung tinggi nilai-nilai pancasila

4. Tidak ugal-ugalan

5. Cinta terhadap tanah air dan Negara

Selain bentuk bhakti diatas cara untuk mengatasi degradasi moral dan penguatan karakter anak, yaitu dari pendidikan non formal terlebih dahulu yang didapatkan dari dalam keluarga itu sendiri. Keluarga merupakan pondasi dasar anak dalam menerima pendidikan dan pembentukan karakter pertama anak, disana peran orang tua sangat penting adanya dalam mengajarkan dan menanamkan nilai-nilai budi pekerti,etika,moral serta menekankan ajaran-ajaran agama dari sejak dini. Dalam ajaran agama hindu yang tertuang dalam Canakya Nitisastra, Bab III, Sloka 18 yang berbunyi sebagai berikut:

\section{"Lalayet panca-varsani \\ Dasa-varsani tadayet \\ Prapte tu sodase varse \\ Putram mitravadacaret"}

Terjemahanya :

"Asuhlah anak dengan cara memanjakannya sampai berumur lima tahun,memberi hukuman-hukuman selama sepuluh tahun berikutnya. Jikalau ia sudah menginjak usia enam belas tahun didiklah ia dengan cara berteman."

Dari kutipan diatas dapat diartikan bahwasanya disaat anak masih berumur 0-5 tahun segala pendidikan dan pembiasaan akan mudah diserapnya. Oleh karena itu 
berilah mereka contoh-contoh yang baik dan positif, jangan bersikap kasar kepada anak sebab memori anak akan sangat cepat menangkapnya. Didiklah anak dengan penuh kelembutan dan kasih sayang serta didik anak secara perlahan. Disini peran orang tua harus mampu menanamakan sikap-sikap yang berbudi luhur mengajarkan hal mana yang boleh dilakukan dan hal mana yang tidak boleh dilakukan sehingga anak dapat membedakan perbuatan yang baik dan tidak baik dilakukan serta tidak lupa untuk menanamkan ajaran-ajaran agama,etika,moral maupun lainya. Memberikan hukuman yang dimana maksudnya ialah didiklah anak dan ajarkan ia rasa tanggung jawab sehingga nantinya ia bisa memiliki rasa tanggung jawab terhadap sesuatu yang ia kerjakan nantinya. Namun ketika anak melakukan kesalahan bimbinglah dan nasehatilah ia,beri kesempatan anak untuk memperbaiki kesalahannya yang ia perbuat, memberi hukuman bukan berati memukul atau memberikan kekerasan bagi anak itu sendiri karena ini akan sangat berpengaruh terhadap mental dan pertumbuhan anak itu sendiri. (Pratama Kemenuh, 2017). Kemudian didukung oleh peran guru pengajian atau guru di sekolah sebagai pendidikan formal anak. Sekolah menjadi salah satu lembaga dalam membentuk atau menumbuh kembangkan nalar berfikir anak melalui pengetahuan yang diajarkan pendidik. Pendidikan yang didapatkan di dalam sekolah merupakan pendidikan lanjutan pembentukan dan pengutan karakter yang didapatkan dirumah. Selain mengajarkan ilmu pengetahuan seorang pendidik juga harus dapat menumbuh kembangkan karakter anak didiknya, karena pendidikan yang baik adalah pendidikan yang mampu mengubah kepribadian anak menjadi pribadi yang lebih baik lagi. Selain peran guru agama hindu dan budi pekerti dalam mendidik dan menanamkan ajara-ajaran agama. Guru lainnya juga memiliki kewajiban yang sama dalam membentuk serta membina karakter anak dengan mengajarkan kedesiplinan, tanggung jawab, etika, sopan santun, membangun keimanan peserta didik dengan cara melakukan persembahyangan atau doa sebelum memulai pembelajaraan. (Jahroh \& Sutarna, 2016) dari segi guru wisesa atau guru pemerintah upaya dalam mencegah degradasi moral ini ialah dengan memperkuat lagi peraturah-peraturan atau tata tertib yang berlaku di masyarakat, memberikan sanksi bagi orang-orang yang melanggar, selain itu pemerintah dalam membuat pembaharuan-pembaharuan peraturan juga harus melihat dari berbagai sisi sehingga tidak terjadinya penyimpangan. Dari segi pendidikan,pemerintah berwajib memberikan fasilitas ataupun sarana dan pasarana yang lengkap dan memadai di sekolah, sehingga fungsi sekolah sebagai lembaga pendidikan akan bisa lebih efektif serta mampu melahirkan anak bangsa yang menjadi pionir - pionir pembangunan ke arah yang diharapkan. Pemerintah juga harus mampu dalam membuat kurikulum-Kurikulum yang baik sehingga membantu guru dalam mendidik peserta didik. Selanjutnya dengan adanya guru Swadyaya ini yang memiliki peran penting dan utama dalam kehidupan,beliau yang bersifat maha gaib dan adil bagi setiap insan didunia ini yang betentangang dengan ajaran dharma maka beliu akan secara tidak langsung memberikan teguran melalui alam tanpa kita sadari. Karena kita mempercayai setiap perbuatan yang kita lakukan akan menghasilkan buah karna (Karmaphala).

\section{SIMPULAN}

Dari pembahasan diatas dapat disimpulkan bahwa degradasi moral merupakan hal yang sangat mengkhawatirkan apa lagi di tambah dengan situasi dunia saat ini yang sangat kacau akibat Pandemi Covid-19, karena hal tersebut dapat lebih memicu pemerosotan karakter bagi generasi muda. Pendidikan karakter merupakan tombak 
utama dalam membangun generasi muda yang berbudi pekerti luhur. Melalui peran catur guru ini diharapkan dapat mengatasi degradasi moral pada diri anak maupun generasi muda saat ini. Oleh karena itu peran catur guru ini memiliki peranan yang sangat penting dalam menanamkan nilai-nilai etika,moral dan budi pekerti luhur yang mampu mendidik generasi muda menjadi pribadi yang berkarakter. Ke-empat guru ini harus saling bersinergi dan berkesinabungan satu dengan yang lainya,karena hal tersebut merupakan tanggung jawab dan kewajiban dari catur guru. Sehingga mampu terciptanya tujuan hidup yang disebut dengan istilah "Moksatam Jagadita Ya Ca Iti Dharma” yang

artinya ialah tujuan hidup manusia adalah untuk mencapai kesejateraan serta kebahagiaan dalam hidup maupun akhirat.

\section{DAFTAR PUSTAKA}

Ari Lastini,Ni Nyoman. Anggreni, N. M. (2018). Bentuk Ajaran Catur Guru di Sekolah Dasar Negeri 11 Sanur Kecamatan Denpasar Selatan Kota Denpasar. Adi Widya, Jurnal Pendidikan Dasar.

Arta Jaya, K. (2019). Membangun Mutu Pendidikan Karakter Siswa Melalui Imlemtasi Ajaran Tri Hita Karana. Jurnal Penjaminan Mutu.

Darta, I. N. (2020). Pendidikan Agama Hindu Dalam Pembentukan Kepribadian Siswa. Guna Widya: Journal Pendidikan Hindu, 7.

Dwi Lestari, Ida Ayu, Sutriyanti, N. K. (2020). Implementasi Pembelajaraan Catur Guru dalam Membentuk Karakter Siswa. Jurnal Pendidikan Agama Hindu Jaya Pangus Press, 20.

https://jurnal.stkipahsingaraja.ac.id/index.php/wspah/article/view/71

Hindu, M. (2016). Pengertian Catur Guru dan Bagian-Bagianya Serta Contohnya.

Jahroh, W. S., \& Sutarna, N. (2016). Pendidikan Karakter Sebagai Upaya Mengatasi Degradasi Moral. Prosiding Seminar Nasional Inovasi Pendidikan, 395-402.

Mulyadi,Seto,Basuki,Heru,Rahardjo, W. (2016). Psikologi Pendidikan. PT.RajaGrafindo Persada.

Nurhayati, ni ketut. (2020). 7466, p-ISSN : 1907-9559 Jurnal Widya Sastra Pendidikan Agama Hindu 39 PENDIDIKAN AGAMA HINDU UNTUK MEMBANGUN GENERASI MUDA YANG BERKARAKTER DI MASA PANDEMI COVID 1.

Pratama Kemenuh, I. B. (2017). Solusi Terhadap Degradas. ADI WIDYA : Jurnal Pendidikan Dasar, 1(1), 35-43. http://ejournal.ihdn.ac.id/index.php/AW SOLUSI

Ramadhani, N. (2020). Pentingnya Memahami Fungsi dan Tujuan dari Pendidikan. https://www.akseleran.co.id/blog/pendidikan-

adalah/amp/\#aoh=16215120271314\&referrer=https\%3A\%2Fwww.google.com \&amp_tf=Dari \%25\%24s

Sri Mertasari, N. M. (2016). Model Evaluasi Pendidikan Karakter Yang Komprehensif. Seminar Nasional, Riset Inovatif.

Suantara, I. W. (2020). Peran Pendidikan Agama Hindu Dalam Membentuk Karakter Siswa Di Tengah Pandemi Covid 19. Jurnal Widya Sastra Pendidikan Agama Hindu, 3(1), 73-80. https://jurnal.stkipahsingaraja.ac.id/index.php/wspah/article/view/71

Suardana, M. (n.d.). Ajaran Catur Guru dalam Penguatan Karakter Peserta Didik. 
Sudarsana, i ketut. dewi kristina. (2011). strategi pembelajaraan pendidikan agama hindu dalam membentuk karakter siswa. 21(3), 269-279.

Yaniasti, N. L. (2019). Pembentukan Karakter Anak Melalui Catur Guru. Jurnal Pendidikan Daiwi Widya, 06(1), 1-11. 